\title{
Properties of Papercrete Concrete: Building Material
}

\author{
Mr. Yogesh D. Shermale ${ }^{1}$, Dr. Mahaveer B. Varma ${ }^{2}$ \\ ${ }^{1}$ Assistant Professor, Civil Engineering Department, CSMSS Polytechnic College, Aurangabad. \\ ${ }^{2}$ Associate Professor,Applied Mechanics Department, Government College of Engineering, Aurangabad.
}

\begin{abstract}
A detailed investigation on papercrete specimen of size $100 \times 100 \times 100 \mathrm{~mm}$ made with different ingredients like sand, fly ash and glass fiber was carried out after 28 days of air curing. Papercrete is a new construction material made with waste paper, cement and water. Papercrete had been used to build low cost homes without much knowledge of its structural properties. The purpose of this study is to obtain compressive strength and mass density of papercrete by doing some trial mixes of papercrete with different ingredients. From this study it has been observed that the papercrete is a lightweight material and it can be used as an infill material in high rise buildings.
\end{abstract}

Keywords:papercrete, wastepaper, compressive strength, mass density, lightweight material.

\section{Introduction}

The emission of $\mathrm{CO}_{2}$ from construction sites due to use of cement is a major issue for all the countries. On the other hand, people's desire to live in an eco-friendly environment is continuous increasing due to awareness. Consequently this study is carried out in order to resolve these kinds of issues. Papercrete is a new composite material made using waste paper. Papercrete reduces the amount of cement volume and make environment friendly building material. [1]

Papercrete is a material originally developed 80 years ago but it is recently rediscovered. Papercrete is a mixture of cement, sand, and paper. When combined and cured, these materials produce a product similar to concrete; however, it is very lightweight. Furthermore, the cost efficiency gained by utilizing the ample supply of recycled paper reinforces the need for the research of this alternative. All portions of the encasement structure have different strength requirements. For example, the centerline of a beam does not need a large compressive strength. By adding paper we can reduce the construction material density and use material in an efficient manner, we maintain a structurally sound building at a lower cost. It was decided to study papercrete to measure its strength, workability, and other properties to determine if it could be used to reduce the cost of buildings. [2]

Papercrete has good sound absorption characteristics. Papercrete made with some special mixes is resistant to fire, fungi, and pests of all kinds. Papercrete blocks made with a sufficient quantity of Portland cement and sand are fire resistant. We can make papercrete blocks fireproof by coating them with a solution of boric acid and borax and using a concrete sealer papercrete blocks can be made waterproof.

Due to the light weight of Papercrete building blocks it can be used for interior walls in high-rise buildings in seismically active areas. Using papercrete building blocks in place of conventional or concrete bricks/blocks could reduce the dead load of structure and reduce the steel percentage and the depth of foundations required. Use of wastepaper in concrete could become an economical and profitable substitute to landfills, incinerator, or other use options. [3]

\section{Research Significance}

Building material industry has witnessed an increased demand from the last decade due to an increased demand of housing for the growing urban population which has caused shortage of building materials. The crisis of raw material shortfalls is faced by the relevant industry to fulfill the increased demand of building materials. This situation has levied the need for searching other substitutes of raw materials. Consequently as a result of this search for raw materials; the conversion of the industrial wastes to useful building and construction material has evolved as a substitute over conventional raw materials. By doing this not only the industrial waste will be recycled and used as building materials but there will be economic design of buildings. The use of wastepaper covers two conflicting social agendas; the first one is the present need of the low-cost housing and the other is the booming interest in construction materials that are created with minimum harm to the environment, the so called sustainable design trend that is being embraced by developers, architects, and engineers alike.

\section{Experimental Procedure}

Papercrete cube specimens of size $100 \times 100 \times 100 \mathrm{~mm}$ and 18 different cases were investigated. The variables include different cement, sand, fly ash and glass fiber proportions. The different proportions of paper with other ingredients are shown in the Table 1 . The production of papercrete is easy. Production requires an 
accurate measurement of ingredients. It is important to weight the waste papers before soaking them as it will be difficult afterwards to calculate the original weight of paper. The process of making papercrete includes soaking waste paper in water overnight so that the fibers are softened and then agitating the mix thoroughly to obtain a homogeneous pulp. The Portland cement, sand and water are added to the pulp and mixed. The mixture is then poured into moulds to create cubes and the forms are removed after 24 hours. After 28 days of air curing the cubes are ready for testing (Fig.1). [4]

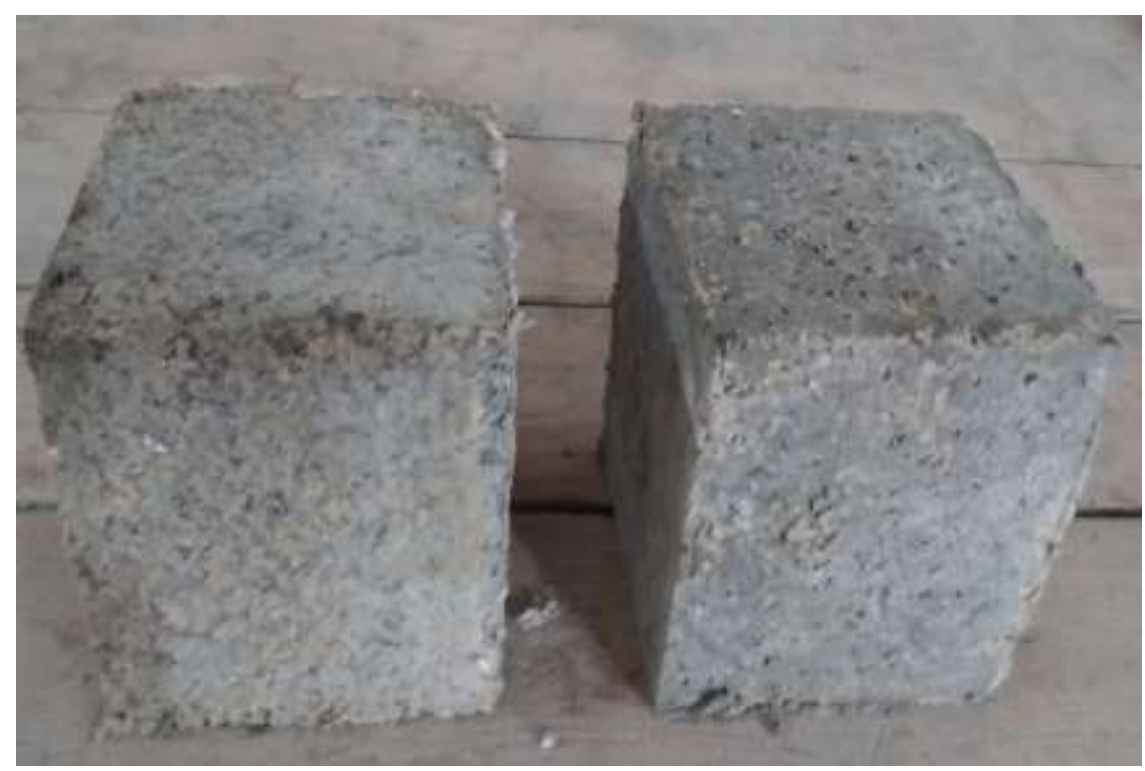

Figure 1:Papercrete Cube Specimen

Table 1: Different Mix Proportions for Papercrete

\begin{tabular}{|c|c|c|c|c|c|c|c|c|}
\hline \multirow[t]{2}{*}{ Group } & \multirow{2}{*}{$\begin{array}{c}\text { Mix } \\
\text { no. }\end{array}$} & \multirow[t]{2}{*}{ Material } & \multirow[t]{2}{*}{ Proportion } & \multicolumn{5}{|c|}{ Quantities of Material in gm. } \\
\hline & & & & Paper & Cement & Sand & $\begin{array}{l}\text { Fly } \\
\text { Ash }\end{array}$ & $\begin{array}{l}\text { Glass } \\
\text { Fiber }\end{array}$ \\
\hline \multirow{3}{*}{ A } & 1 & Paper/Cement & $1-1$ & 500 & 500 & - & - & - \\
\hline & 2 & Paper/ Cement & $1-2$ & 500 & 1000 & - & - & - \\
\hline & 3 & Paper/Cement & $1-3$ & 500 & 1500 & - & - & - \\
\hline \multirow{3}{*}{ B } & 4 & Paper/ Cement/Sand & $1-1-5$ & 500 & 500 & 2500 & - & - \\
\hline & 5 & Paper/ Cement/Sand & $1-1-3$ & 500 & 500 & 1500 & - & - \\
\hline & 6 & Paper/ Cement/Sand & $1-1-2$ & 500 & 500 & 1000 & - & - \\
\hline \multirow{3}{*}{$\mathrm{C}$} & 7 & Paper/Cement/Fly Ash & $1-0.7-0.3$ & 500 & 350 & - & 150 & - \\
\hline & 8 & Paper/Cement/Fly Ash & $1-0.6-0.4$ & 500 & 300 & - & 200 & - \\
\hline & 9 & Paper/Cement/Fly Ash & $1-0.5-0.5$ & 500 & 250 & - & 250 & - \\
\hline \multirow{3}{*}{$\mathrm{D}$} & 10 & Paper/ Cement/Sand/Fly Ash & $1-.7-2-.3$ & 500 & 350 & 1000 & 150 & - \\
\hline & 11 & Paper/ Cement/Sand/Fly Ash & $1-.7-3-.3$ & 500 & 350 & 1500 & 150 & - \\
\hline & 12 & Paper/ Cement/Sand/Fly Ash & $1-.7-5-.3$ & 500 & 350 & 2500 & 150 & - \\
\hline \multirow{3}{*}{$\mathrm{E}$} & 13 & Paper/ Cement/Glass Fiber & $1-2-0.5 \%$ & 500 & 1000 & - & - & 2.5 \\
\hline & 14 & Paper/ Cement/Glass Fiber & $1-2-0.75 \%$ & 500 & 1000 & - & - & 3.75 \\
\hline & 15 & Paper/ Cement/Glass Fiber & $1-2-1 \%$ & 500 & 1000 & - & - & 5.00 \\
\hline \multirow{3}{*}{$\mathrm{F}$} & 16 & Paper/ Cement/Sand/Glass Fiber & $1-1-3-0.5 \%$ & 500 & 500 & 1500 & - & 2.50 \\
\hline & 17 & Paper/ Cement/Sand/Glass Fiber & $1-1-3-0.75 \%$ & 500 & 500 & 1500 & - & 3.75 \\
\hline & 18 & Paper/ Cement/Sand/Glass Fiber & $1-1-3-1 \%$ & 500 & 500 & 1500 & - & 5.00 \\
\hline
\end{tabular}

\section{Specimen}

The compressive strength was determined of cube size $100 \times 100 \times 100$ mmusing Universal Testing Machine (UTM). The test setup is shown in fig. 3. Two aluminum plates were used to uniformly distribute the load given by the machine to the sample.

\section{Items of Investigation}

At the age of 28 days, papercrete specimens were tested for compressive strength of concrete as per IS: 5161959. Also before testing, the weight of samples was taken to calculate density of the material. 


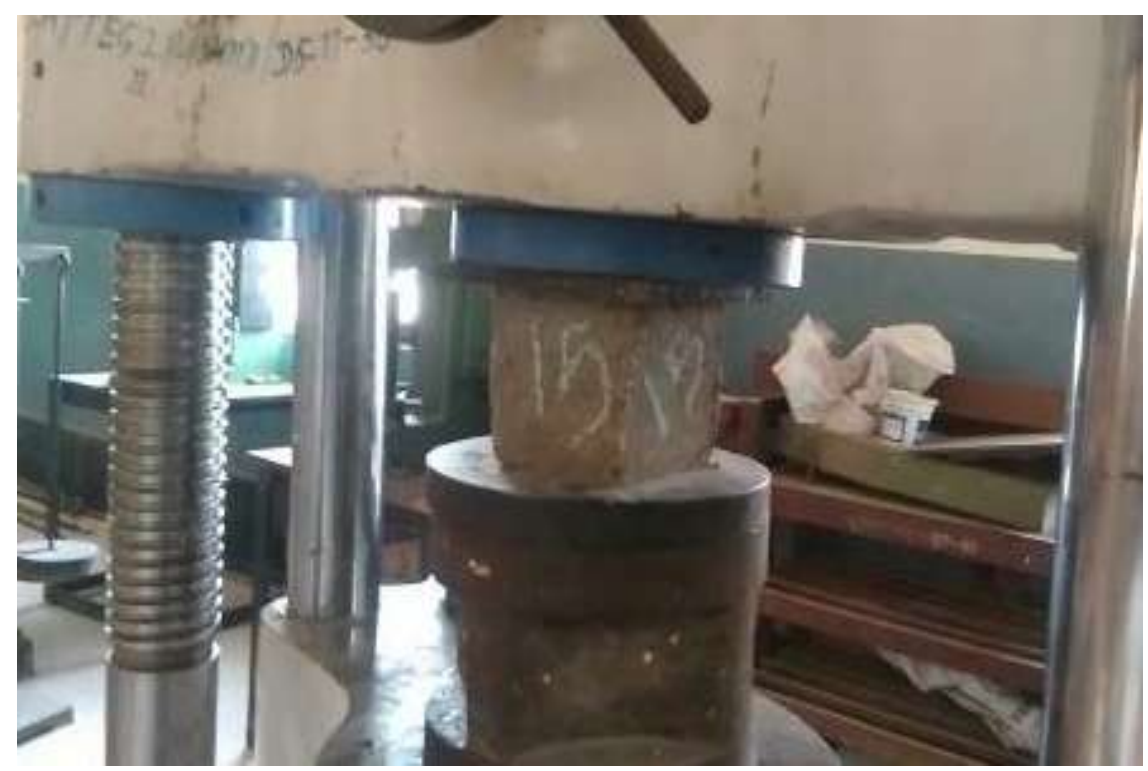

Figure 2: Compression Test Setup

\section{A. Waste Paper:}

\section{Materials}

Paper is the main ingredient of papercrete and hence the properties of papercrete depend on the microstructure of paper used. Due to the anisotropic nature of paper; the quality and strength of its fibers, differs depending on several factors. They are, the type of wood, the percentage of recycled paper, the amount of water in the pulp, the way of pulping (chemical or mechanical) and the speed of drying. Table 2 shows the properties of dry paper used.

Table 2: Properties of Dry Paper Properties Values

\begin{tabular}{|l|l|}
\hline \multicolumn{1}{|c|}{ Properties } & \multicolumn{1}{|c|}{ Values } \\
\hline Weight & $47 \mathrm{GSM}$ \\
\hline Thickness & $0.06 \mathrm{~mm}$ \\
\hline Moisture & $7.5 \%$ \\
\hline Bursting Strength & $168 \mathrm{kPa}$ \\
\hline Tearing resistance & $12.6 \mathrm{~kg}$ \\
\hline Tensile Strength & $1.13 \mathrm{~kg}$ \\
\hline
\end{tabular}

\section{B. Cement:}

Ordinary Portland cement of 43 grade was used for the entire work.

\section{Sand:}

The fine sand confirming to the zone - I was used. The fineness modulus and specific gravity of sand were 3.4 and 2.52 respectively.

\section{Fly ash :}

Fly ash used was collected from the Dirk India Private limited, Nasik and confirming to the class-F. The physical properties of fly ash are described in Table 3.

Table 3: Physical composition of Fly ash

\begin{tabular}{|c|l|l|l|l|}
\hline Sr. No & \multicolumn{1}{|c|}{ Physical properties } & \multicolumn{1}{|c|}{ Unit } & \multicolumn{1}{|c|}{$\begin{array}{c}\text { Processed fly ash used in } \\
\text { Experimental work }\end{array}$} & \multicolumn{1}{|c|}{$\begin{array}{c}\text { Specification as per } \\
\text { IS 3812:1991 }\end{array}$} \\
\hline 1 & Sample name & - & P -100 & - \\
\hline 2 & Color & - & Grayish white & - \\
\hline 3 & Residual retained on $45 \mu$ sieve & $\%$ & 1.6 & 34 (maximum) \\
\hline 4 & $\begin{array}{l}\text { Fineness -specific surface area by } \\
\text { Blaine's permeability method }\end{array}$ & $\mathrm{m}^{2} / \mathrm{kg}$ & $600(2928)$ & $320(1561.6)$ \\
\hline 5 & Specific gravity & - & - & 2.25 \\
\hline 6 & Moisture content & $\%$ & 0.5 & 2 (maximum) \\
\hline 7 & Soundness by Autoclave & $\%$ & 0.1 & 0.8 (maximum) \\
\hline
\end{tabular}




\section{E. Cem-FILL Anti-Crack HD Glass Fibers}

Cem-FILL Anti-Crack, Alkali-resistant glass fiber, has been specially developed for the reinforcement of cementation mortars and concrete mixes. When introduced into a conventional concrete mix, it reinforces effectively the same by adding millions of dispersed fibers per cubic meter of concrete [5].

Table 4: Properties of Cem-fill Anti- Crack HD fibers

\begin{tabular}{|c|l|l|}
\hline Sr. No. & \multicolumn{1}{|c|}{ Property } & \multicolumn{1}{c|}{ Typical Value } \\
\hline 1 & Number of Fibers & $214 \mathrm{millions} / \mathrm{kg}$ \\
\hline 2 & Aspect Ratio & $857: 1$ \\
\hline 3 & Specific Surface Area & $150 \mathrm{~m}^{2} / \mathrm{kg}$ \\
\hline 4 & Tensile Strength & $1700 \mathrm{MPa}$ \\
\hline 5 & Modulus of Elasticity & $72 \mathrm{GPa}$ \\
\hline 6 & Corrosion Resistance & Very High \\
\hline 7 & Specific Gravity & 2.68 \\
\hline 8 & Density & $26 \mathrm{kN} / \mathrm{m}^{3}$ \\
\hline 9 & Filament Diameters & $14 \mathrm{microns}$ \\
\hline 10 & Filament Length & $12 \mathrm{~mm}$ \\
\hline
\end{tabular}

\section{Cem-Fill Anti-Crack HD Glass Fiber gives:-}

1. Ideal aspect makes for excellent early-age performance.

2. Greater modulus of elasticity for an effective long-run, even for the hardened concrete.

3. The qualitative reinforcing material with no least cover that is non-rusting.

4. It does not protrude to the finished surface.

Cem-fill Anti-fibers can be simply added to the mix either on site or at mixing plant without the need for any special equipment. Certain standard concrete mix designs are used for this purpose. Extended mixing times are redundant.Properties of Cem-fill Anti-fibers are given Table 4 and it is shown in fig. 2.

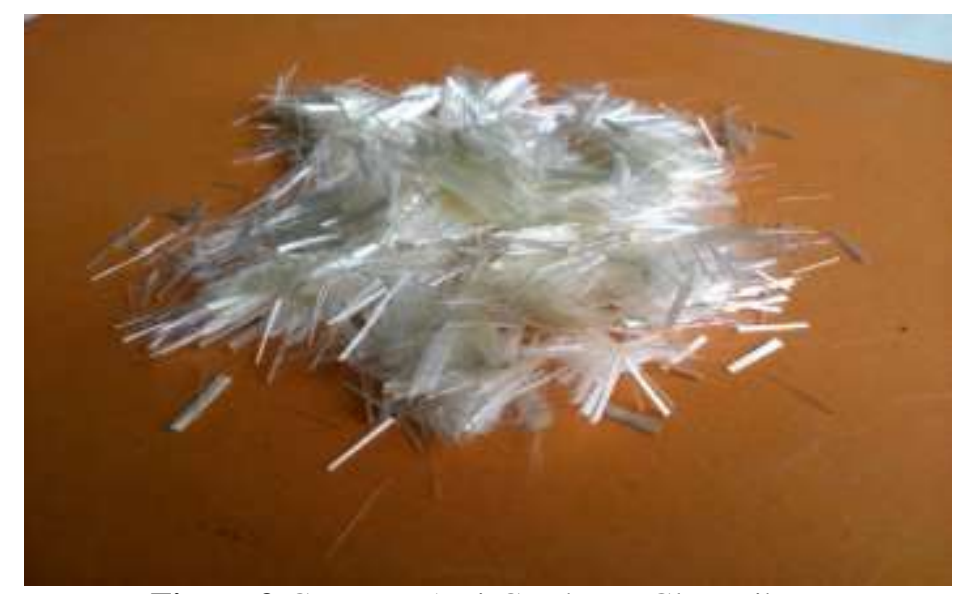

Figure 3:Cem-FIL Anti-Crack HD Glass Fibers

\section{a. Weight and Density}

\section{Result And Discussion}

Table 5 indicates the mass densities of all the papercrete specimens. It was observed from the table; as the cement and sand content is increased into the papercrete, the density papercrete increases and vice versa. From the fig. 4 it is observed that maximum weight density obtained in group B which is $1.117 \mathrm{gm} / \mathrm{cm}^{2}$. The cubes made from papercrete were lighter than the normal concrete cubes to the maximum extent of $57 \%$ by density.

Table 5: Mass Density of Papercrete Specimen

\begin{tabular}{|c|c|l|l|c|}
\hline Group & Mix no. & \multicolumn{1}{|c|}{ Material } & \multicolumn{1}{|c|}{ Proportion } & Ave. Mass Density $\left(\mathrm{gm} . / \mathrm{cm}^{3}\right)$ \\
\hline \multirow{3}{*}{ A } & 1 & Paper: Cement & $1: 1$ & 0.433 \\
\cline { 2 - 5 } & 2 & Paper: Cement & $1: 2$ & 0.614 \\
\cline { 2 - 5 } & 3 & Paper: Cement & $1: 3$ & 0.793 \\
\hline \multirow{2}{*}{ B } & 1 & Paper: Cement: Sand & $1: 1: 2$ & 1.117 \\
& 2 & Paper: Cement: Sand & $1: 1: 5$ & 0.914 \\
\cline { 2 - 5 } & 3 & Paper: Cement: Sand & $1: 0.7: 0.3$ & 0.778 \\
\hline C & 1 & Paper :Cement: Fly Ash & $1: 0.6: 0.4$ & 0.416 \\
\cline { 2 - 5 } & 2 & Paper : Cement : Fly Ash & & 0.475 \\
\hline
\end{tabular}




\begin{tabular}{|l|l|l|l|l|}
\hline & 3 & Paper : Cement : Fly Ash & $1: 0.5: 0.5$ & 0.478 \\
\hline \multirow{3}{*}{ D } & 1 & Paper: Cement : Sand : Fly Ash & $1: 7: 3: .3$ & 0.965 \\
\cline { 2 - 5 } & 2 & Paper: Cement : Sand : Fly Ash & $1: 7: 2: 3$ & 0.809 \\
\cline { 2 - 5 } & 3 & Paper: Cement : Sand : Fly Ash & $1: 7: 5: 3$ & 1.100 \\
\hline \multirow{3}{*}{ E } & 1 & Paper: Cement: Glass Fiber & $1: 2: 0.5 \%$ & 0.728 \\
\cline { 2 - 5 } & 2 & Paper: Cement: Glass Fiber & $1: 2: 1 \%$ & 0.664 \\
\cline { 2 - 5 } & 3 & Paper: Cement: Glass Fiber & $1: 1: 3: 0.5 \%$ & 0.671 \\
\hline \multirow{2}{*}{ F } & 1 & Paper: Cement : Sand : Glass Fiber & $1: 1: 3: 0.75 \%$ & 0.953 \\
\cline { 2 - 5 } & 2 & Paper: Cement : Sand : Glass Fiber & $1: 1: 3: 1 \%$ & 0.981 \\
\cline { 2 - 5 } & 3 & Paper: Cement : Sand : Glass Fiber & 0.943 \\
\hline
\end{tabular}

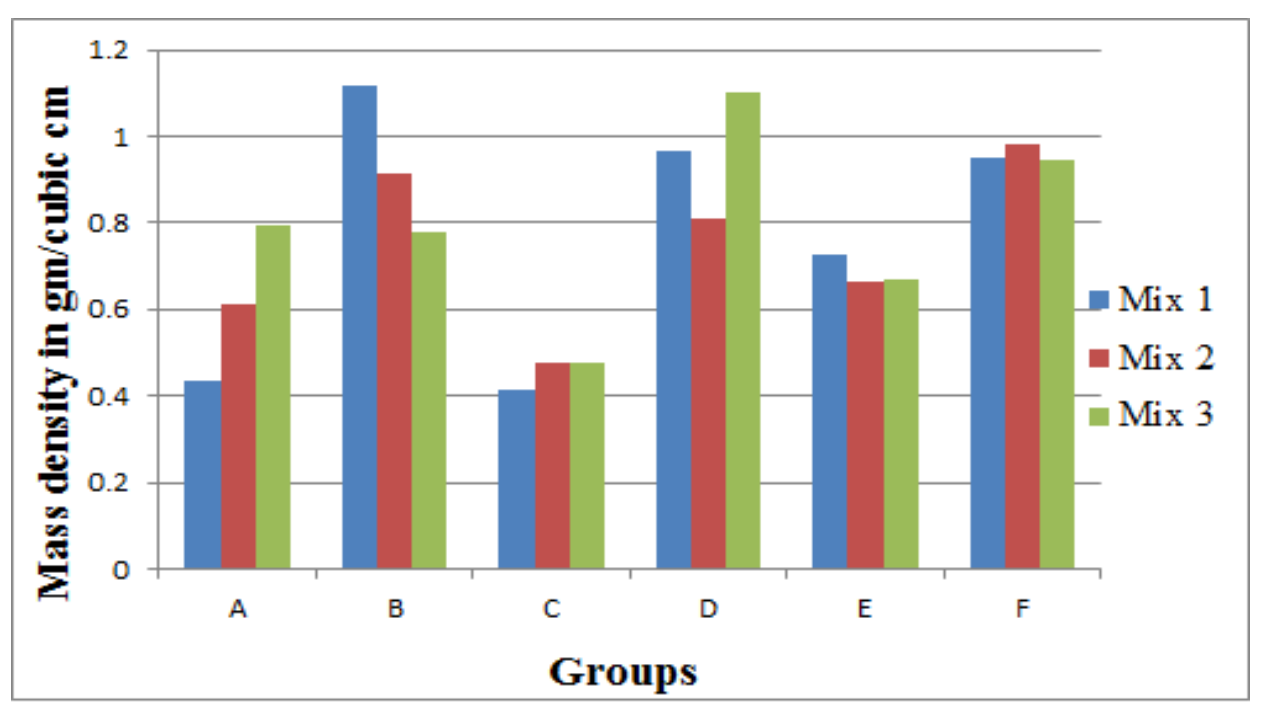

Figure 4: Mass densities of mixes of Different Groups

\section{b. Compressive Strength}

The compressive strength of the papercrete varies with composition. The compressive strength test was taken from two samples. Table 6 shows results of compressive testing. From the fig. 5 it is observed that maximum compressive strength obtained in group $\mathrm{F}$ which is $5 \mathrm{MPa}$. Only group $\mathrm{E}$ and $\mathrm{F}$ gives the strength more than 3.5 MPa due to addition of glass fiber. Here also Cement plays an important role of binding the ingredients in mix.

Table 6: Compressive Strength Results of Papercrete Specimen

\begin{tabular}{|c|c|c|c|c|}
\hline Group & Mix no. & Material & Proportion & Compressive Strength $(\mathrm{MPa})$ \\
\hline \multirow[t]{3}{*}{ A } & 1 & Paper:Cement & $1: 1$ & 1.9 \\
\hline & 2 & Paper: Cement & $1: 2$ & 2.3 \\
\hline & 3 & Paper:Cement & $1: 3$ & 2.5 \\
\hline \multirow[t]{3}{*}{ B } & 1 & Paper: Cement:Sand & $1: 1: 2$ & 2.5 \\
\hline & 2 & Paper: Cement:Sand & $1: 1: 3$ & 3.3 \\
\hline & 3 & Paper: Cement:Sand & $1: 1: 5$ & 3.5 \\
\hline \multirow[t]{3}{*}{$\mathrm{C}$} & 1 & Paper:Cement:Fly Ash & $1: 0.7: 0.3$ & 2.5 \\
\hline & 2 & Paper:Cement:Fly Ash & 1:0.6:0.4 & 1.6 \\
\hline & 3 & Paper:Cement:Fly Ash & $1: 0.5: 0.5$ & 1.8 \\
\hline \multirow[t]{3}{*}{$\mathrm{D}$} & 1 & Paper: Cement:Sand:Fly Ash & $1:: 7: 3: .3$ & 2.6 \\
\hline & 2 & Paper: Cement:Sand:Fly Ash & $1: .7: 2: .3$ & 2.3 \\
\hline & 3 & Paper: Cement:Sand:Fly Ash & $1: .7: 5: .3$ & 3.1 \\
\hline \multirow[t]{3}{*}{$\mathrm{E}$} & 1 & Paper: Cement:Glass Fiber & $1: 2: 0.5 \%$ & 3.8 \\
\hline & 2 & Paper: Cement:Glass Fiber & $1: 2: 0.75 \%$ & 4.0 \\
\hline & 3 & Paper: Cement:Glass Fiber & $1: 2: 1 \%$ & 4.3 \\
\hline \multirow[t]{3}{*}{$\mathrm{F}$} & 1 & Paper: Cement:Sand:Glass Fiber & $1: 1: 3: 0.5 \%$ & 4.5 \\
\hline & 2 & Paper: Cement:Sand:Glass Fiber & $1: 1: 3: 0.75 \%$ & 4.8 \\
\hline & 3 & Paper: Cement:Sand:Glass Fiber & $1: 1: 3: 1 \%$ & 5.0 \\
\hline
\end{tabular}




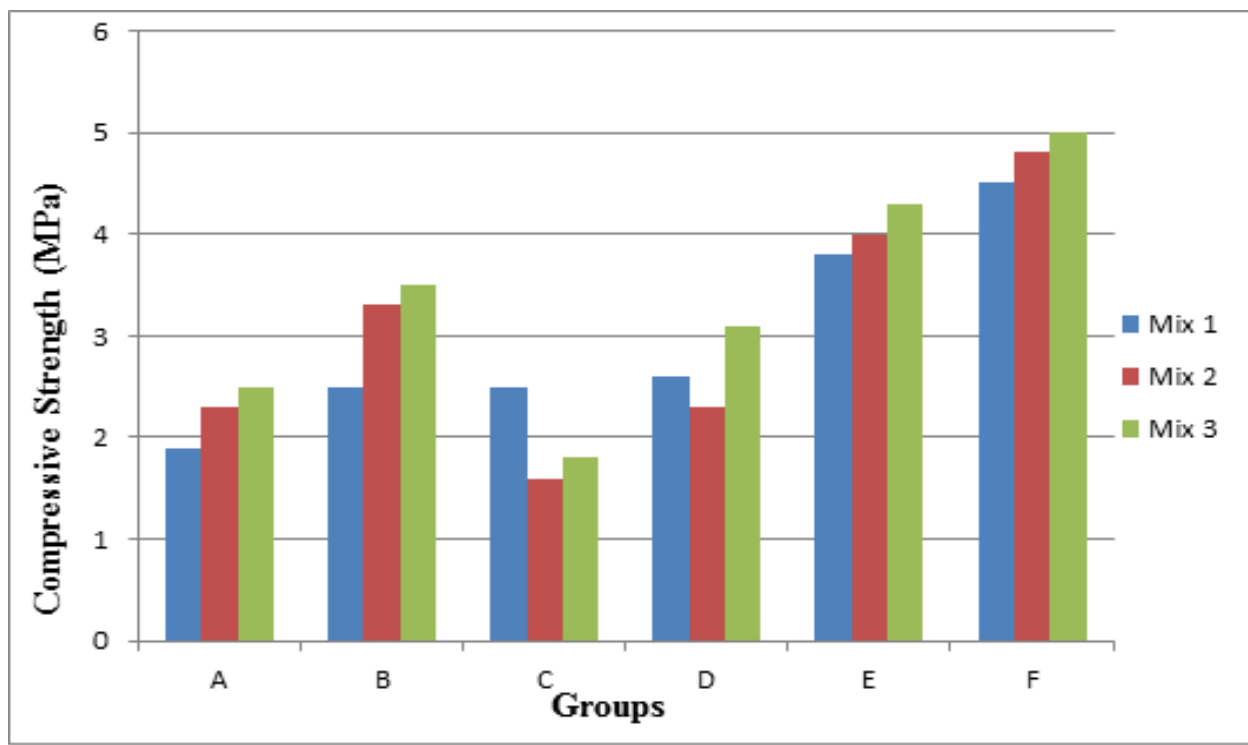

Figure 5: Compressive Strength of different Papercrete Groups

\section{Conclusions}

1. Cement plays an important role in the compressive strength and behavior. Specimens with higher proportion of cement exhibit larger compressive strength.

2. In each group of papercrete mixes, compressive strength of concrete decreased with the increase of the amount of wastepaper and vice versa.

3. The low density of papercrete indicates that they are lightweight and can be used in the form of either hollow or solid blocks for making walls of buildings, in high-rise buildings. This property also makes papercrete good for building arches and domes.

\section{References}

[1]. Fuller, B. J.; Fafitis, A. P.; and Santamaria, J. "Structural properties of a new material made of waste paper"Building Integration Solutions (AEI) 2006, pp. 1-16.

[2]. Titzman, L. C. " "Analysis of Low Cost Building Material for the Mix Alco Process” Texas A \& M University, 2006.

[3]. Shukeri, R. B. and a Naser, A. G. "Concrete Mix with Wastepaper" 2nd international conference on built environment in developing countries (ICBEDC 2008), pp. 567-575.

[4]. Yun, H.; Jung, H.; Choi, C., "Mechanical Properties of Papercrete Containing Waste Paper", Architectural Institute of Korea, 2007.

[5]. Mandlik, D. N. and Varma, M. B. "Effect of Anti-Crack High dispersion Glass Fibers on Split Tensile Strength of Self Compacting Concrete", International Journal for Scientific Research \& Development (IJSRD),Vol. 3, Issue 07, ISSN (online): 2321-0613, pp.216-219, 2015.

[6]. Akinwumi, I.; Olasunkanmi, M. O.; Oluwarotimi, M. O.; Paul, O. A. " Structural Evaluation Of Lightweight Concrete Produced Using Waste Newspaper And Office Paper " Civil And Environmental Research, ISSN 2224-5790 (paper) ISSN 2225-0514 (online) Vol.6, no.7, 2014, pp 160-168.

[7]. Shermale, Y. D. and Varma, M. B. " Papercrete: An Efficient Use of Waste Paper " Recent Trends in Civil Engineering and Technology, ISSN: 2249-8753(Online), ISSN: 2321-6476(Print) Volume 5, Issue 3, 2016, pp 54-59. 